\title{
GERAKAN PEMBANGUNAN DESA SEMESTA NASIONAL MELALUI PEMBERDAYAAN GAPOKTAN PADANGAN DALAM PENGELOLAAN LIMBAH
}

\author{
Hardo Wahyudi ${ }^{1}$, Surya Priyambudi ${ }^{2}$, Ahmat Firmansyah ${ }^{3}$, Joko Slamet ${ }^{4}$, Yulinda Prastika ${ }^{5}$ \\ ${ }_{1,2,3,4,5}$ Universitas Wijaya Putra
}

hardowahyudi@uwp.ac.id_ surya@uwp.ac.id, jslamet8@gmail.com,yulindaprastika18@gmail.com

\begin{abstract}
Abstrak
Desa Randupadangan merupakan salah satu desa yang terletak di Kecamatan Menganti Kabupaten Gresik. Komoditi pertanian utama didesa ini adalah padi dan jagung. Selain itu didesa ini terdapat kelompok tani (gapoktan) yang mengelola peternakan sebanyak 9 ekor sapi perah. Seluruh sapi dipelihara dalam kandang dengan kondisi semi permanen, sehingga kotoran sapi kurang lebih $135 \mathrm{~kg}$ setiap harinya harus dibersihkan agar kandang selalu dalam keadaan bersih. Kurangnya pengetahuan dan kesadaran masyarakat menjadikan limbah kotoran sapi tersebut belum termanfaatkan secara maksimal yaitu dengan membuangnya kesungai atau disekitar kandang. Akibatnya terjadi pencemaran lingkungan baik darat, air maupun udara dan menjadikan image desa menjadi kurang bersih. Metode yang dilaksanakan oleh tim untuk mengurangi permasalahan tersebut yaitu : penyuluhan, FGD dan pendampingan pembuatan pupuk cair (POC) dan kompos dari bahan dasar limbah kotoran sapi. Hasil dari kegiatan ini gapoktan padangan : 1) Terbentuknya unit pengolahan limbah terpusat, 2) Terwujudnya desa mandiri dalam pengolahan limbah, 3) Meningkatkan kesejahteraan masyarakat, 4) Terjadinya peningkatan keterampilan 69,56\% pada pembuatan pupuk cair dan 65,22\% dalam pembuatan pupuk kompos. Program pemberdayaan gapoktan padangan berbasis pengelolaan limbah merupakan upaya untuk mendukung gerakan pembangunan Desa Semesta Nasional yaitu salah satu program pemerintah dalam mewujudkan desa mandiri berbasis masyarakat dan sumber daya alam lokal.
\end{abstract}

Kata Kunci : pengolahan limbah, POC, kompos, gapoktan, desa mandiri

\begin{abstract}
Randupadang Village is one of the villages located in Menganti District, Gresik Regency. The main agricultural commodities in this village are rice and corn. In addition, this village has a farmer group (gapoktan) which manages the farm of 9 dairy cows. All cows are kept in a semi-permanent cage, so that approximately $135 \mathrm{~kg}$ of cow dung every day must be cleaned in order to have a clean condition cage. Unfortunately, cow dung waste has not been utilized optimally. The society there prefer to dump it into the river or around the cage. It is caused by lacking of knowledge and public awareness. As a result, environmental pollution, including land, water and air, has made the image of the village less clean. The methods implemented by the team to reduce these problems are: counseling, FGD and assistance in making liquid fertilizer (POC) and compost from cow dung waste as basic ingredients. The results of this activity Gapoktan Padangan: 1) The establishment of a centralized waste treatment unit, 2) The establishment of an independent village in waste treatment, 3) The improvement of community welfare. 4) There was an skills increase $69.56 \%$ increase in making liquid fertilizer (POC) and $65.22 \%$ in making compost. The waste management of Gapoktan Padangan based on empowerment program is an effort to support 'Desa Semesta Nasional' development movement, which is one of the government programs in realizing an independent village based on community and local natural resources.
\end{abstract}

Keywords: waste treatment, POC, compost, gapoktan, independent village 


\section{PENDAHULUAN}

Menurut Catatan Sipil Desa, Desa Randupadangan merupakan salah satu desa yang terletak di Kecamatan Menganti Kabupaten Gresik, memiliki luas wilayah $378.0 \mathrm{Ha}$ dengan jumlah penduduk 4.586 jiwa yang terbagi menjadi dua dusun, Dusun Randu terdiri dari 2 RT dan $1 \mathrm{RW}$ dengan jumlah keseluruhan 1.215 kepala keluargasedangkan Dusun Padangan terdiri dari 20 RT dan 6 RW 3.371 kepala keluarga.

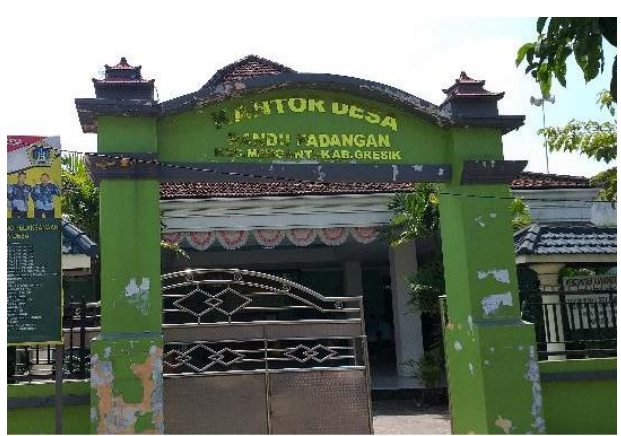

Gambar 1. Plakat Desa Randupadangan

Tabel 1. Jenis Pekerjaan Masyarakat Randupadangan

\begin{tabular}{lcc}
\hline \multicolumn{1}{c}{ Pekerjaan } & Jumlah & Prosentase \\
\hline Karyawan Swasta & 908 & $20 \%$ \\
Petani & 550 & $12 \%$ \\
Pedagang & 490 & $11 \%$ \\
Buruh Tani & 340 & $7 \%$ \\
Pertukangan & 165 & $4 \%$ \\
Lainnya & 2138 & $46 \%$ \\
\hline
\end{tabular}

Sumber : catatan sipil desa

Berdasarkan tabel 1 menunjukkan prosentase yang didapatkan $20 \%$ (908 orang) menjadi karyawan swasta, 12\% (550 orang) petani, 11\% (490 orang) pedagang, 7\% (340 orang) buruh tani, 4\% (165 orang) pertukangan, dan 46\% (2.138 orang) lain- lain.

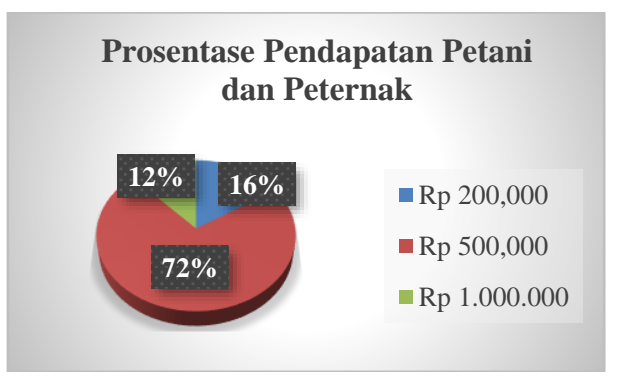

Gambar 2. Pendapatan Peternak dan Petani
Berdasarkan gambar 2 diatas dapat disimpulkan bahwa Pendapatan tersebut merupakan pendapatan untuk satu rumah dengan total per bulan. Dilihat dari rata rata jumlah pendapatan yang diperoleh dapat disimpulkan bahwa warga termasuk dalam taraf ekonomi menengah kebawah.

Berdasarkan data dilapangan dengan yang dilakukan oleh tim dengan Bapak Anhar (kepala desa) dan Bapak Sulaiman (ketua gapoktan padangan) melalui observasi dan wawancara menyampaiakan bahwa komoditi utama masyarakat Desa Randupadangan adalah sector pertanian dan peternakan, hal tersebut diperkuat dengan data catatan sipil tahun 2018 bahwa Desa Randupadangan memiliki $372.1 \mathrm{Ha}$ pertanian/perkebunan dan 3 peternakan besar. Dimana terdapat 950 ekor sapi, 1.500 ekor kambing dan 3.500 ekor unggas merupakan dari sektor peternakan sedangkan dari sektor pertanian/perkebunan terdapat cabai merah 10 ton/Ha, padi 25 ton/Ha dan buah-buahan 10 ton/Ha.

Berdasarkan Komoditi pertanian utama didesa ini adalah padi dan jagung. Selain itu didesa ini terdapat kelompok tani aktif (gapoktan padangan) yang mengelola peternakan sebanyak 9 ekor sapi perah. Seluruh sapi dipelihara dalam kandang dengan kondisi semi permanen, sehingga kotoran sapi kurang lebih $135 \mathrm{~kg}$ setiap harinya harus dibersihkan agar kandang selalu dalam keadaan bersih.

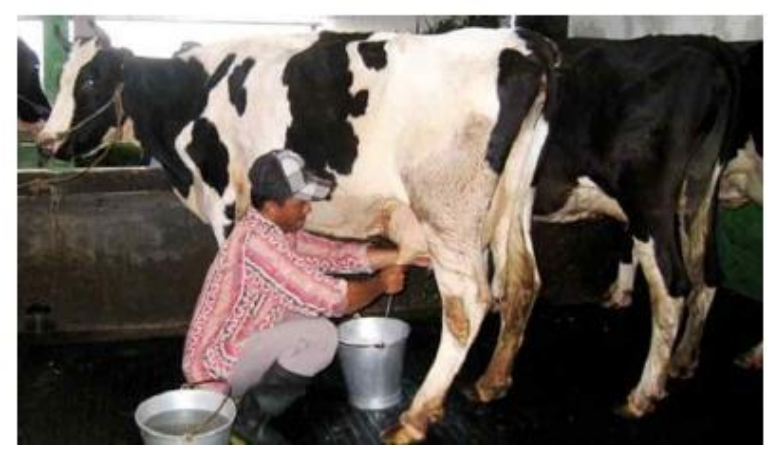

Gambar 3. Peternakan Gapoktan Padangan

Kurangnya pengetahuan dan kesadaran masyarakat menjadikan limbah kotoran sapi tersebut belum termanfaatkan secara maksimal yaitu dengan membuangnya kesungai atau disekitar kandang. Akibatnya terjadi pencemaran lingkungan baik darat, air maupun udara dan menjadikan image

Lingkungan Hidup Dan Kebencanaan 
desa menjadi kurang bersih. Hal tersebut ditegaskan bahwa penumpukan sampah dalam jangka panjang akan berakibat pada persoalan bau dan pencemaran air (Buhani, 2018; Mutaqin, 2010; Widiyanto, Yuniarno, \& Kuswanto, 2015).

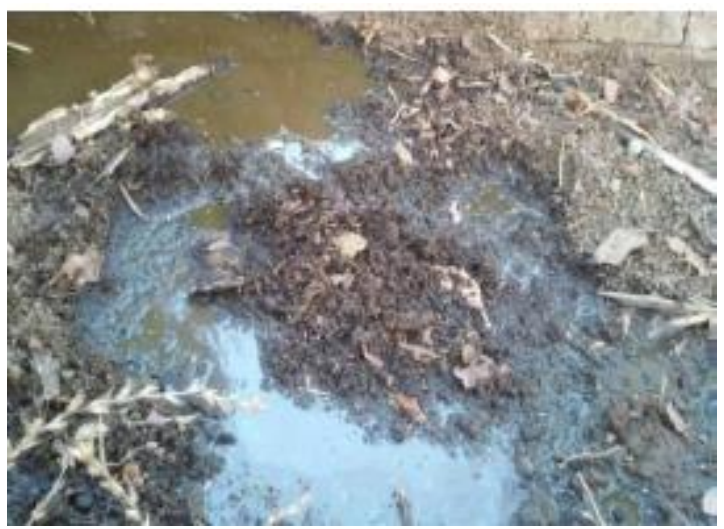

Gambar 4. Kotoran sapi yang dibuang sembarangan

Berdasarkan permasalahan tersebut diatas maka perlu adanya solusi untuk mengatasi permasalahan tersebut yaitu pemberdayaan gapoktan padangan dalam pengelolan limbah organik dan kotoran sapi sehingga masyarakat akan lebih berdaya dan menciptakan desa mandiri berbasis masyarakat dan sumber daya alam lokal sebagai upaya mendukung gerakan pembangunan Desa Semesta Nasional.

Pemberdayaan masyarakat merupakan strategi dalam perubahan sosial secara terencana dan ditujukan untuk mengatasi masalah ataupun memenuhi kebutuhan masyarakat. Nasdian ( 2014) menyatakan bahwa pemberdayaan merupakan suatu proses yang ditujukan untuk membantu masyarakat memperoleh daya untuk mengambil keputusan dan menentukan tindakan yang akan ia lakukan, termasuk mengurangi efek hambatan pribadi dan sosial dalam melakukan tindakan. Diamana pemberdayaan memiliki tujuan yang akan dicapai. Menurut Ife dan Tesoriero (2008) menyatakan bahwa pemberdayaan masayarakat bertujuan meningkatkan keberdayaan dari mereka yang dirugikan. Dalam proses pemberdayaan, masyarakat mendapatkan pembelajaran sehingga dapat secara mandiri melakukan upaya-upaya perbaikan kualitas kehidupannya. Dengan demikian, maka proses tersebut harus dilaksanakan dengan adanya keterlibatan penuh masyarakat secara bertahap, terus-menerus, dan berkelanjutan.

Berdasarkan Undang-Undang Republik Indonesia Nomor 19 Tahun 2013 tentang Perlindungan \& Pemberdayaan Petani pada Pasal 1 Ayat 2 menyatakan bahwa pemberdayaan petani merupakan segala upaya untuk meningkatkan kemampuan petani untuk melaksanakan usaha tani yang lebih baik melalui pendidikan dan pelatihan, penyuluhan dan pendampingan, pengembangan sistem dan sarana pemasaran hasil pertanian, konsolidasi dan jaminan luasan lahan pertanian, kemudahan akses ilmu pengetahuan, teknologi dan informasi, serta penguatan kelembagaan Petani perlu diberikan perlindungan serta pemberdayan supaya petani memiliki kapasitas untuk terus tumbuh dan berkembang menjadi lebih sejahtera.

Wrihatnolo dan Dwidjowijoto (2007) menyatakan terdapat tiga proses utama dalam pemberdayaan yaitu : 1) Tahap penyadaran, pada tahap ini target sasaran adalah masyarakat yang kurang mampu yang harus dengan memberikan penyadaran akan hak yang mereka miliki untuk mampu dalam menghadapi masalah. Mereka harus diberikan motivasi sehingga mereka mempunyai kemampuan untuk keluar dari lingkaran kemiskinan. 2) Tahap pengkapasitasan, pada tahap ini terdiri dari tiga jenis pengkapasitasan : pengkapasitasan manusia, organisasi serta sistem nilai. Pengkapasitasan manusia dapat dilakukan dengan memberikan pendidikan, pelatihan, dan kegiatan lainnya untuk meningkatkan keterampilan individu atau kelompok. 3) Tahap penyadaran, pada tahap ini target sasaran diberikan daya atau kekuatan, kekuasaan, otoritas atau peluang yang disesuaikan dengan kemampuan yang dimiliki maka target sasaran dapat menjalankan kekuasaan yang diberikan serta mampu membawa perubahan lebih baik kedepannya.

Menurut Inayati (2019) menyatakan bahwa Hakikat pemberdayaan itu sendiri adalah bagaimana membuat masyarakat mampu membangun dirinya dan memperbaiki kehidupannya sendiri. Adapun istilah mampu diatas mengandung makna: berdaya, paham, termotivasi, memiliki kesempatan, melihat 
dan memanfaatkan peluang, berenergi, mampu bekerjasama, tahu sebagai alternatif, mampu mengambil keputusan, berani mengambil risiko, mampu mencari dan menangkap informasi serta mampu bertindak sesuai inisiatif. Menurut Suharto (2014) indikator pemberdayaan paling tidak memiliki empat hal, yaitu kegiatan yang terencana dan kolektif, memperbaiki kehidupan masyarakat, prioritas bagi kelompok lemah atau kurang beruntung, serta dilakukan melalui program peningkatan kapasitas yaitu dengan memberikan pendidikan, pelatihan, dan kegiatan lainnya untuk meningkatkan keterampilan individu atau kelompok.

\section{METODE}

Tujuan pemberdayaan ini adalah memberikan keterampilan kepada gapoktan padangan dalam pengolahan limbah dan memberikan kontribusi dalam mengembangkan keterampilan yang sudah dimiliki oleh anggota. Sebagaimana penelitian yang dilakukan oleh Wesa dan Suryono (2014) bahwa kontribusi pelatihan terhadap peserta pelatihan yakni dapat meningkatkan sumber daya manusia (SDM), membangkitkan semangat untuk berkoperasi dan berwirausaha, serta membantu masyarakat dalam meningkatkan ekonomi keluarganya.

Menurut Wahyudi (2019) adapun metode pelaksanaan dalam pengabdian adalah sebagai berikut :

1. Waktu dan Tempat Pelaksanaan : pada tahap ini menjelaskan kapan dan dimana pelaksanaan program pemberdayaan ini dilaksanakan

2. Alat dan bahan : menjelaskana ala dan bahan apa saja yang digunakan oleh tim baik bahan habis pakai, bahan penunjanag ataupun laiannnya

3. Persiapan : pada tahap ini mejelakasan tahapan yang dilakukan tim sebelum dilaksanakan program pemberdayaan masyarakat meliputi pembuatan modul dan pemilihan lokasi pendirian pengolahan limbah terpusat

4. Pelaksanaan : pada tahap pelaksanaan menjalaskan tahapan-tahap dalam pemberdayaan mualai dari sosialisasi dan praktik pendampingan pengolahan limbah

5. Monitoring dan Evaluasi : monitoring dan evaluasi bertujuan untuk melihat perkembangan Program Pengabdian Masyarakat yang dilakukan. Melalui tahap monitoring maka diketahui kendala yang terjadi pada mitra sehingga dapat diketahui solusi yang akan dilakukan.

6. Kaderisari

Pada tahap kaderisasi dilakukan dengan membentu pengurus unit pengolahan limbah. Kaderisasi dilakukan melalui pelatihan pemanfaatan limbah kotoran sampah dan limbah organic yang bertujuan untuk menanamkan jiwa nol sampah pada generasi penerus sehingga nantinya program ini dapat berjalan berkelanjutan

\section{HASIL DAN PEMBAHASAN}

\section{Waktu dan Tempat Pelaksanaan}

Program ini dilaksanakan di Desa Randupadangan Kecamatan Menganti Kabu Paten gresik dengan mitra sasaran Gapoktan Padangan. Waktu pelaksanaan pengabdian ini yaitu selama 6 bulan yakni mulai tahap persiapan hingga pelaporan.

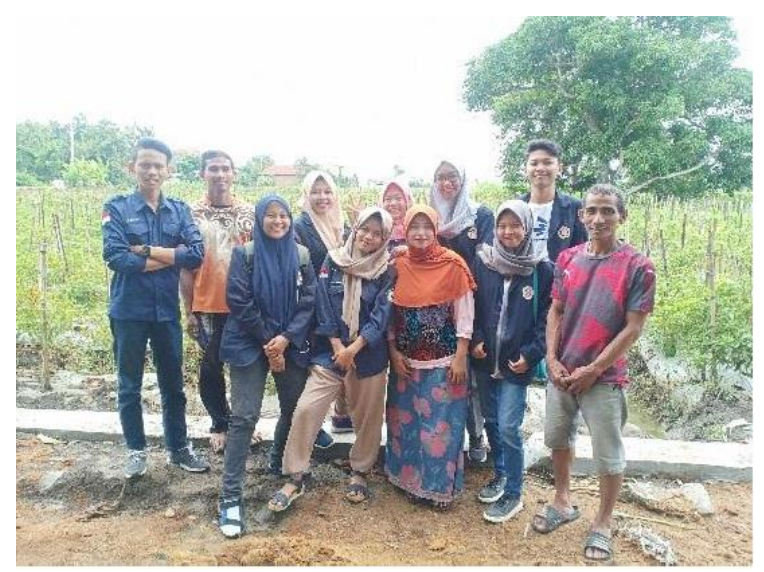

Gambar 5. Tim dan Pengurus Gapoktan Padangan

\section{Alat dan Bahan}

Peralatan yang digunakan dalam pembuatan teknologi pengolahan POC dan kompas yaitu drum plastik, pipa PVC 1/2“, corong, saringan, terpal, gergaji, sekrop, gunting, dan pisau. Alat yang digunakan tersebut merupakan hasil kerjasama antara tim pelaksana pengabdian masyarakat dengan gapoktan padangan. Sedangkan bahan yang digunakan adalah kotoran sapi dan limbah organik yang ada dikandang sapi,

Lingkungan Hidup Dan Kebencanaan 
sayuran sisa, dedaunan kering dan jerami padi.

\section{Persiapan}

Tahap persiapan dilakukan kurang lebih selama 4-6 minggu. Persiapan yang dilakukan meliputi :

a) Pembuatan modul, pembuatan modul digunakan sebagai media penunjang dalam pelaksanaan program.

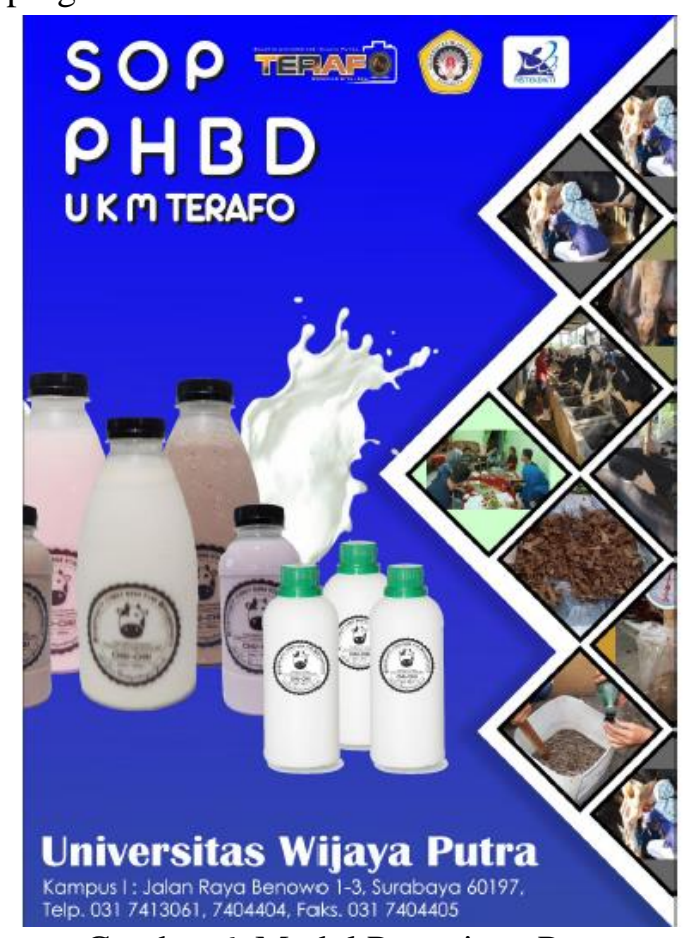

Gambar 6. Modul Penunjang Program

Modul yang dibuat berisi tentang pengenalan konsep pemberdayaan yang akan dilaksanakan, metode pemanfaatan kotoran sapi menjadi pupuk organic cair, metode pemanfaatan limbah organik rumah tangga dan limbah pertanian menjadi kompos,

b) Konsolidasi Awal

Menurut Wahyudi (2018) Pada tahap ini kunjungan kepada mitra dengan tujuan untuk menyatukan sudut pandang antara tim dengan mitra. Dengan sudut pandang yang sama maka akan terjadi kesamaan langkah dalam proses perencanaan, pelaksanaan dan keberlajutan program. Hal ini akan terlihat keterlibatan atau partisiapasi masyarakat yang besar. Konsolidasi awal ini laksanakan di Kantor Kepala Desa Randupadangan dan dilanjutkan dirumah Bapak Sulaiaman sebagai Ketua Gapoktan Padangan

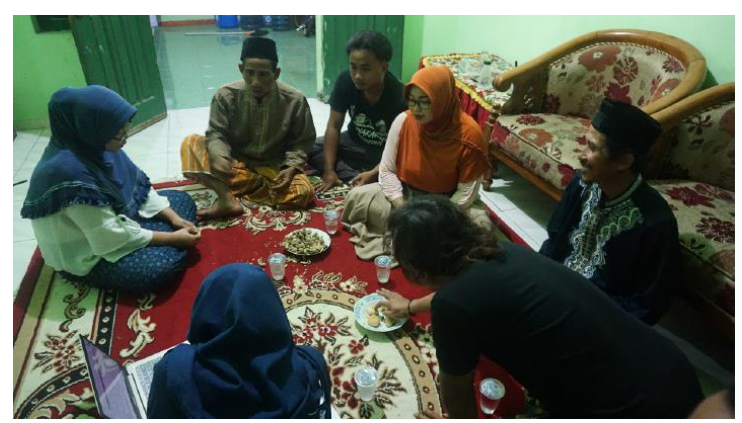

Gambar 7.Konsolidasi Tim dan Mitra

c) Pemilihan lokasi pendirian unit pengolahan limbah terpusat,

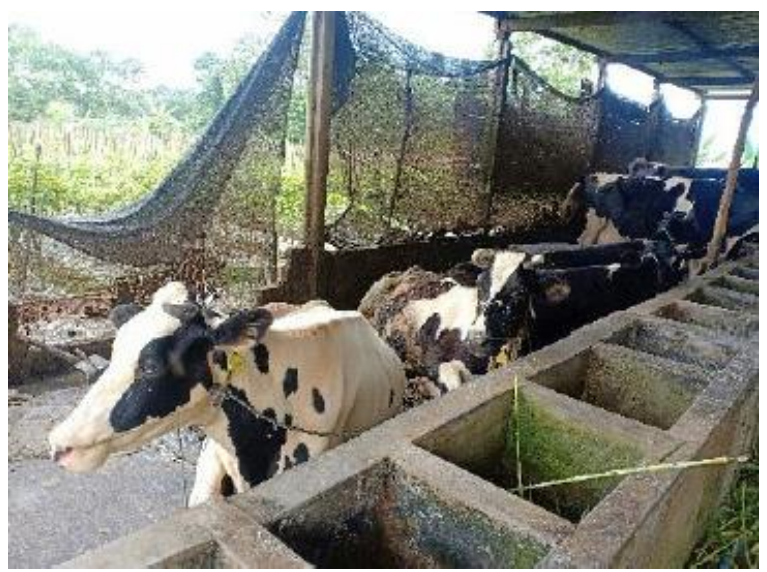

Gambar 8. Kondisi Kandang sapi dan keadaan sekitar yang akan digunakan

Pemilihan lokasi pusat pengolahan sampah di Desa Randupadangan dilakukan pada tahap awal sebelum pelaksanaan program. Pemilihan lokasi dipilih tempat yang strategis, mudah dijangkau oleh masyarakat dan tidak terletak jauh dari kandang sapi. Dimana lokasi yang dipilih sebagai tempat pengolahan limbah terpusat adalah lahan dibelakang kandang sapi milik Bapak Sulaiaman yang terletak di RT 018 RW 006 dengan ukuran lahan $6 \mathrm{~m} \times 10 \mathrm{~m}$. Pemilihan tersebut berdasarkan 
hasil konsolidasi antara tim dengan gapoktan padangan, sehingga akan mempermudah dalam pengeolahan limbah kotoran sapi.

\section{Tahap Pelaksanaan Program Kegiatan:}

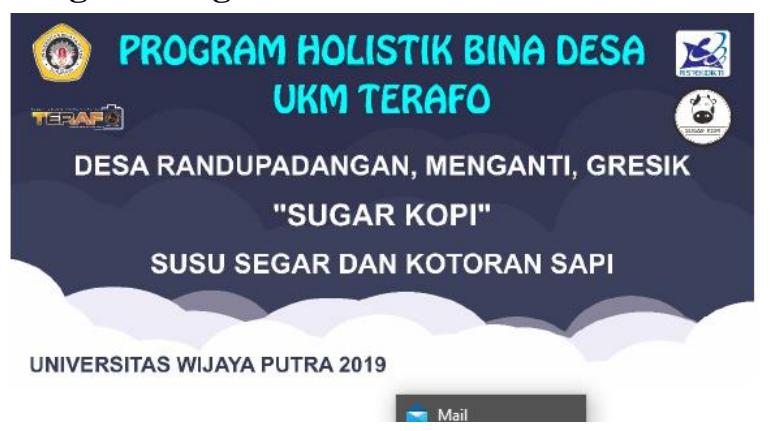

Gambar 9. Program PHBD 2019

Program ini merupakan program pemberdayaan yang dilakukan oleh Tim Hibah Bina Desa UKM Terafo (Terbitan Info) Universitas Wijaya Putra Tahun 2019 yang mendapatkan hibah dari Kementrian Riset, Teknologi dan Pendidikan Tinggi. Dimana program yang diusung oleh tim merupakan upaya untuk mendukung gerakan pembangunan Desa Semesta Nasional yaitu salah satu program pemerintah dalam mewujudkan desa mandiri berbasis masyarakat dan sumber daya alam lokal.

\section{Proses pemberdayaan :}

Pemberdayaan yang dilakukan untuk masyarakat Desa Randupadangan yaitu tentang pengolahan limbak kotoran sapi dan sampah organik. Dengan adanya proses pemberdayaan ini diharapkan masyarakat mampu meningkatkan kemandirian masyarakat, meningkatkan kesejahteraan dan mampu menjaga lingkungan mereka. Adapun metode yang digunakan dalam tahap ini adalah Sosialaisasi, FGD dan praktik dengan mengundang narasumber yang ahli dibidangnya khusunya dalam pengelolaan limbah kotoran sapi dan pembuatan pupuk kompos. Proses pemberdayaan masyarakat dilakukan dengan tiga tahap :
1) Pertama, tahap penyadaran. Tahap ini Gapoktan Padangan diberikan penyadaran melalaui sosialisasi secara lisan yang dilakukan oleh tim. Penyadaran dilakukan dengan tujuan merubah mindset masyarakat tentang dampak dan manfaat kotoran sapi dan sampah organik. Sehingga, Gapoktan Padangan merubah perilakunya dengan menggunakan pupuk organik untuk lahan pertaniannya.

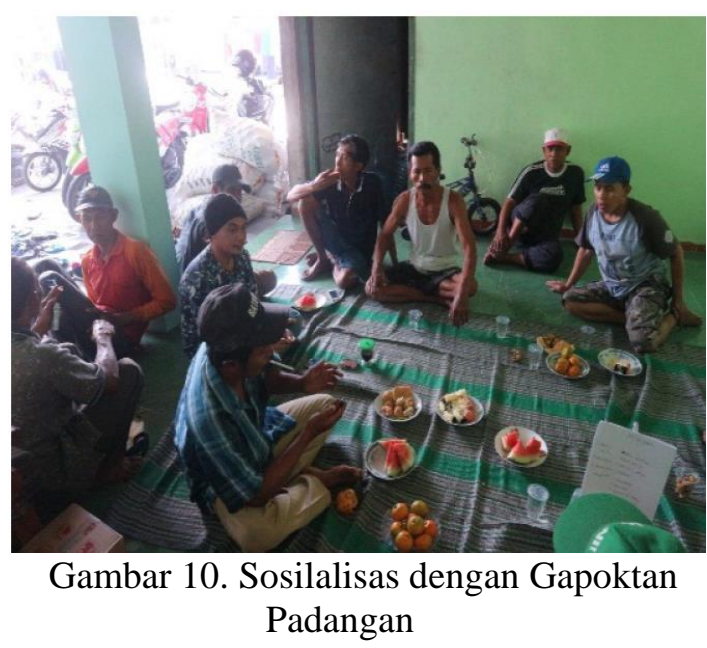

Kegiatan ini dilaksana pada tanggal 25 Mei 2019 dan 04 agustus 2019 di kediaman Bapak Sulaiman (Ketua Gapoktan Padangan) di Desa Randupadangan, Dusun Padangan RT 018 RW 006 diikuti oleh 23 anggota gapoktan dan mengundang narasumber yang ahli dibidangnya yaitu Ir. Faisol Humaidi. Dalam kegiatan tersebut narasumber menyampaiakan materi tentang pengetahuan sampah dan dampak yang ditimbulkannya serta disampaiakan pula metode pemanfaatan kotoran sapi menjadi pupuk organic cair, metode pemanfaatan limbah organik rumah tangga dan limbah pertanian menjadi kompos. Sehingga selain nantinya masyarakat dapat mengelola sampah, masyarakat juga dapat mengkategorikan jenis-jenis sampah dan pengetahuan lainnya. 
2) Kedua, tahap pengkapasitasan. Masyarakat diberian kapasitas atau kemampuan dan ketrampilan yaitu dengan Pelatihann dalam pengolahan limbah kotoran dan sampah organik menjadi POC (pupuk organik cair) dan pupuk kompos.

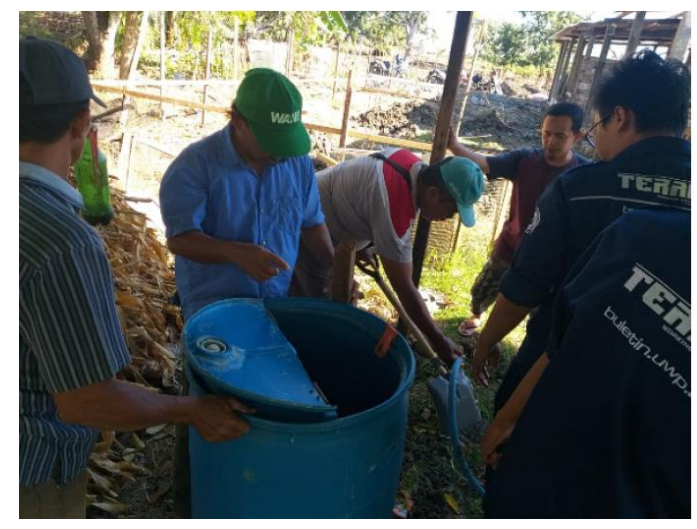

Gambar 11. Pelatihan dan Pendampingan pengolahan limbah

Kegiatan pengolahan limbah menjadi POC dan pupuk kompos dilaksanakan secara bertahap yaitu pada tanggal 18 Agustus 2019 dan pendampingan yang ke 2 pada tanggal 29 September 2019 di kandang sapi milik Gapoktan Padangan yang terletak tidak jauh dari rumah Bapak Sulaiman.

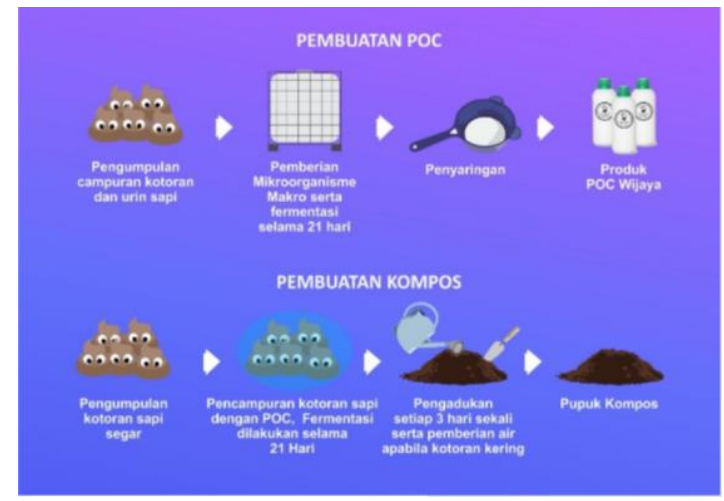

Gambar 12. Skema Pembuatan POC dan Kompos

Adapun skema atau tahapan pembuatan POC dan kompos telah dibuatkan oleh tim dalam bentuk buku atau modul sebagai acuan dalam pelaksanaan kegiatan pengolahan limbah kedepannya, setelah program pemberdayaan ini berakhir.
3) Ketiga, tahap pendayaan. Tahap ini memberikan kekuasaan kepada anggota gapoktan padangan untuk menerapkan program berkelanjutan, masyarakat diberikan kepercayaan untuk mengelola sumber daya yang dimiliki serta kemampuan dan ketrampilan yang telah diberikan.

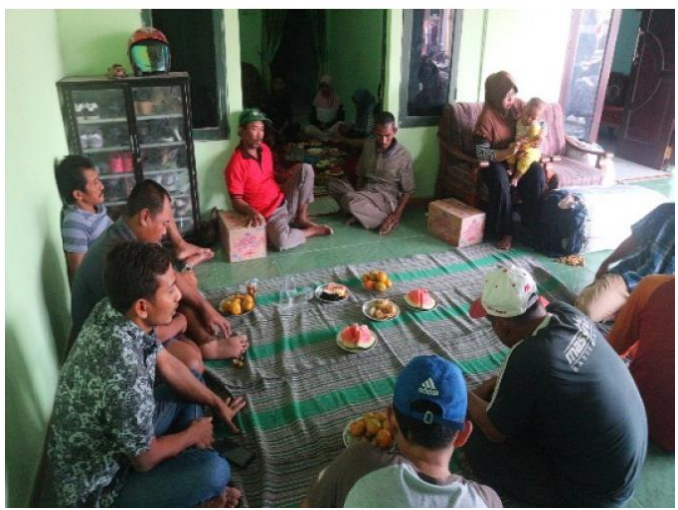

Gambar 12. Konsolidasi Tim dengan Mitra

\section{Aktor Pemberdayaan}

Menurut Narhadi et al (2020) Pengelolaan sampah memerlukan peran aktif masyarakat untuk mengurangi persoalan sampah. Kesadaran dan partisipasi masyarakat mempunyai peranan yang sangat besar dalam pengendalian sampah yang ada. Adapun aktor pemberdayaan yang berperan dalam upaya gerakan desa semesta nasional ini adalah tim Program Holistik Bina Desa dan gapoktan padangan. Dimana tim melakukan pendampingan kepada Gapoktan Padangan untuk mengelola limbah kotoran sapid an sampah organic menjadi POC (pupuk organic cair dan pupuk kompos) sehingga akan tercipta desa mandiri desa mandiri berbasis masyarakat dan sumber daya alam lokal.

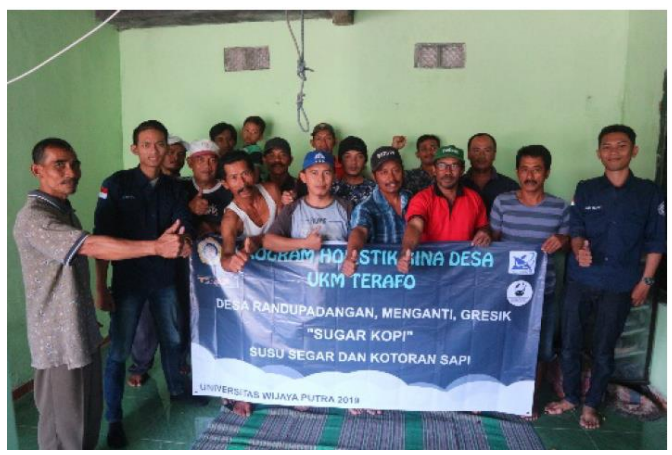

Lingkungan Hidup Dan Kebencanaan 


\section{Gambar 13. Foto Tim dan Gapoktan Padangan}

\section{Capaian Hasil Pemberdayaan}

Indikator ketercapaian program Pemberdayaan Gapoktan Padangan di Desa Randupadangan adalah terwujudnya Desa Randupadangan menjadi desa mandiri dalam pengolahan limbah kotoran sapid an sampah organik. Hal tersebut dapat dilihat dengan tercapainya target luaran sebagai berikut:

1.Terbangunnya Unit Pengolahan Limbah di Desa Randupadangan yaitu di wilayah RT 018 RW 006 di Dusun Randupadangan dengan Gapoktan padangan sebagai koordinator. Saat limbah yang ada di Desa Randupadangan dapat terkelola sehingga jumlah limbah kotoran sapi dan limbah organic lainnhya semakin berkurang.

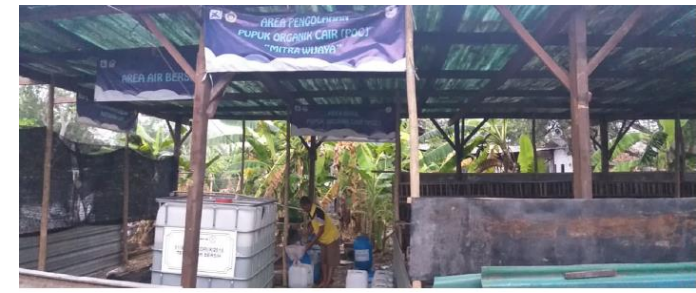

Gambar 14. Instalasi Pengolahan Limbah Terpusat

2. Masyarakat sasaran (Gapoktan Padangan) dapat mengolah limbah kotoran sapi dan limbah organik di Desa Randupadangan menjadi produk-produk bermanfaat yaitu POC (pupuk organic cair) dan pupuk kompo.

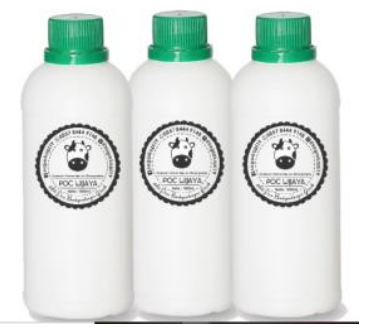

Gambar 15. Kemasan POC

\section{Meningkatkan kesejahteraan masyarakat}

Adanya pengolahan limbah kotoran sapi dan limbah organik maka akan menjadi nilai tambah dari sisi kesejahteraaan masyarakat dimana masyarakat dapat memanfaatkan POC dan Kompos menjadi alternative pengganti pupuk karena telah diuji secara laboratorium secara laboratorium

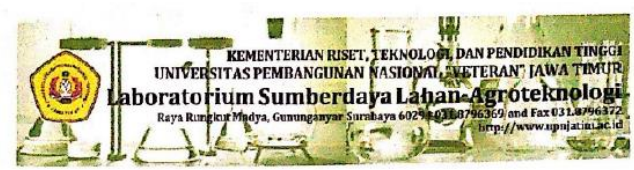

Hasil Analisa Sampel Bahan Punuk Cair
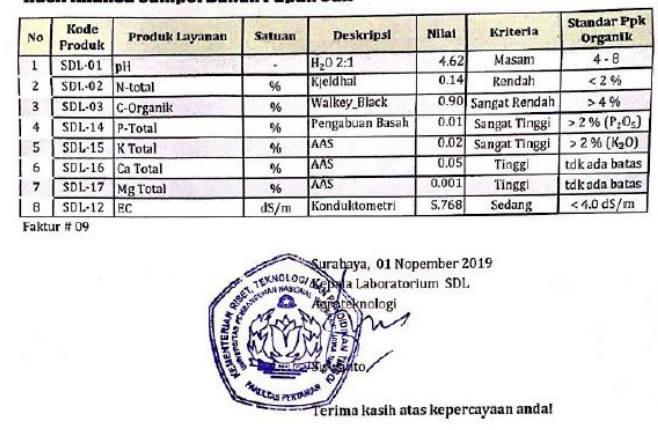

Gambar 16. Hasil Uji Lab POC

\section{Monitoring dan Evaluasi}

Monitoring dilakukan secara langsung ke lokasi mitra. Kendala yang terjadi pada masyarakat sasaran diselesaikan dan dikonsultasikan kepada dosen pembimbing dan beberapa pakar yang ahli dibidangnnya. Monitoring dan evaluasi dilakukan setiap 2 minggu sekali untuk mengetahui perkembangan program pemberdayaan yang dilaksanakan oleh tim.

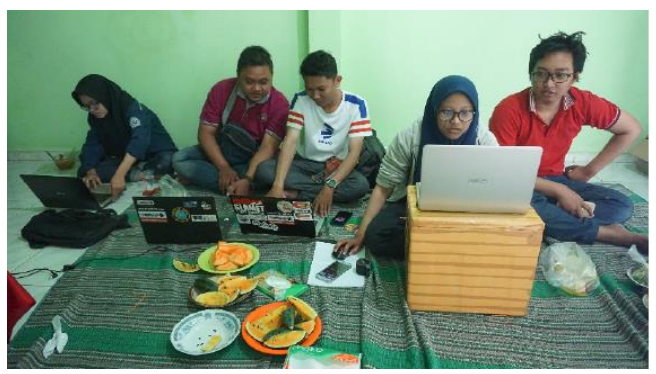


Gambar 17. Konsultasi dengan dosen pembimbing

Gambar 18. Monitoring dan Evaluasi

Beberapa kendala yang ditemukan pada saat monitoring dan solusi penyelesaian yang diberikan dapat dilihat pada tabel 2 dibawah ini.

Tabel 2. Hasil monitoring dan evaluasi

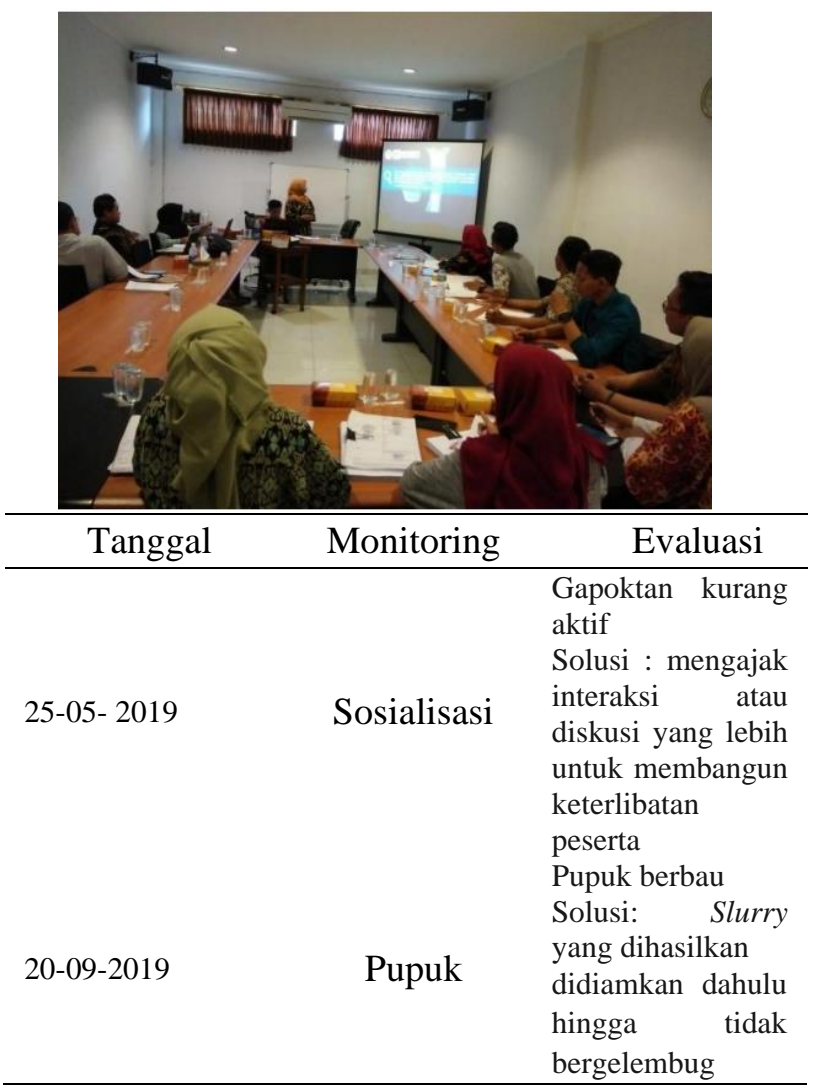

\section{Kaderisasi}

Pada tahap kaderisasi dilakukan dengan membentu pengurus unit pengolahan limbah.

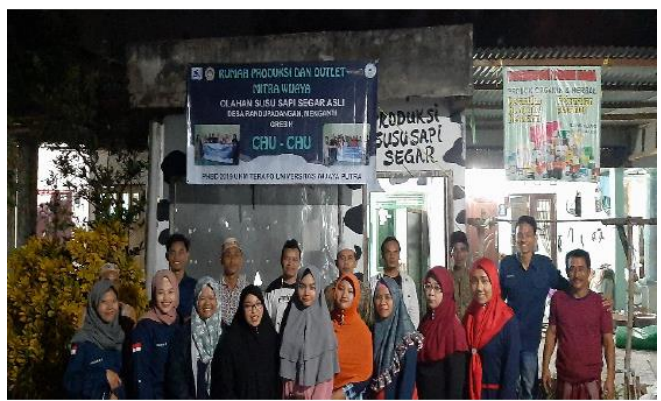

Kaderisasi dilakukan melalui pelatihan pemanfaatan limbah kotoran sampah dan limbah organik yang bertujuan untuk menanamkan jiwa nol sampah pada generasi penerus sehingga nantinya program ini dapat berjalan berkelanjutan. Adapun generasi penerus yang dilibatkan dalam hal ini adalah pemuda karangtaruna Desa Randu Padangan.

Gambar 18. Tim, Karangtaruna dan Gapoktan

Kegiatan pengabdian masyarakat ini sangat berpotensi untuk dilanjutkan karena program ini sangat memberikan manfaat bagi masyarakat dengan semakin berkurangnya limbah di Desa Randupadangan. Program ini berpotensi untuk dilanjutkan dalam jangka panjang dan bekerjasama dengan Pemerintah Kota Gresik, Badan Lingkungan Hidup Kabupaten Gresik, serta Komunitas peduli lingkungan Gresik, Earth and Human (EH) sehingga Desa Randupadangan dapat menjadi desa nol sampah (zero waste village) dan mandiriserta menjadi percontohan bagi desa lainnya.

\section{Pengukuran Peningkatan Keterampilan}

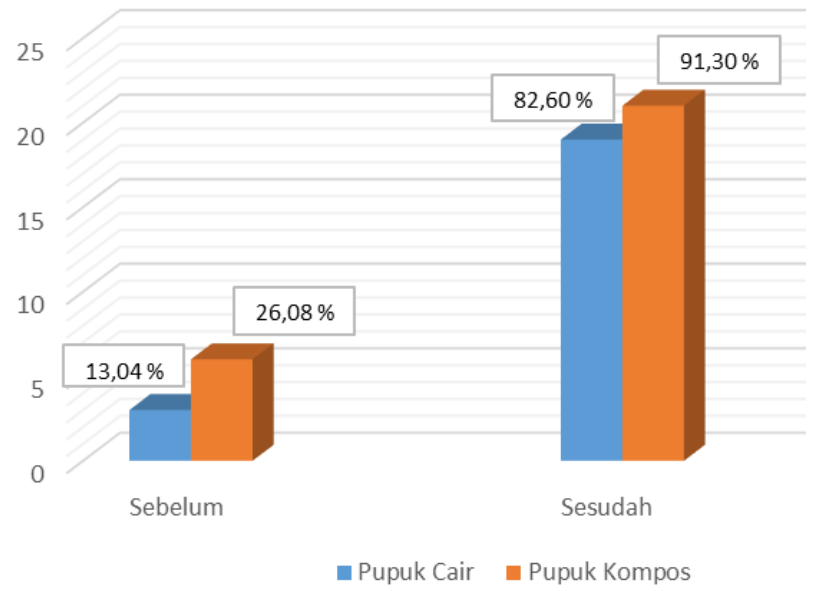

Gambar 19. Rekap hasil pembagian kuesioner sebelum dan setelah penerapan program

Bedasarkan gambar 19 dapat disimpulkan bahwa masyarkat sasaran dapat mengolah limbah kotoran sapi dan limbah organik menjadi pupuk cair dan pupuk kompos. Kuesioner hasil survei yang telah dibagikan kepada masyarakat sasaran sebelum dan setelah penerapan program menunjukkan perubahan peningkatan ketrampilan 69,56\% pada pembuatan 
pupuk cair dan $65,22 \%$ dalam pembuatan pupuk kompos.

\section{KESIMPULAN}

Pemberdayaan Gapoktan Padangan adalah program yang dapat di terapkan di Desa Randupadangan untuk mengatasi permasalahan limbah kotoran sapi dan limbah organik lainnya sehingga mewujudkan Desa Randupadangan yang mandiri dan bebas sampah (zero waste and independent village). Pengolahan limbah yang dilakukan secara terpusat di Unit Pengolahan Limbah dengan Gapoktan Padangan sebagai koordinator utama pelaksanaan program pemberdayaan ini merupakan salah satu upaya mendukung gerakan pemerintah dalam pembangunan Desa Mandiri Nasional berbasis masyarakat dan sumber daya alam lokal.

Adapun hasil yang dicapai dalam pemberdayaan ini adalah Terbentuknya unit pengolahan limbah terpusat, terwujudnya desa mandiri dalam pengolahan limbah dan meningkatkan kesejahteraan masyarakat.

\section{SARAN}

Diperlukan dukungan dan kolaborasi
bersama antara Aparat desa, gapoktan,
karangtaruna dan seluruh masyarakat Desa
Randupadangan maka program pemberdayaan ini
akan berkelanjutan dan menjadikan Desa
Randupadangan sebagai desa percontohan dalam
pengeololan limbah untuk mewujudkan Desa
Mandiri.

\section{UCAPAN TERIMAKASIH}

Terima kasih kami sampaikan kepada : 1) Kementerian Riset, Teknologi dan Pendidikan Tinggi atas dukungannya melalui hibah Progam Holistik Bina Desa tahun 2019, 2) Rektor Universitas Wijaya Putra, 3) Bapak Ibu Dekan dan Ketua Program Studi yang telah memberikan dukungan, 4) Gabungan Kelompok Tani (Gapoktan) Padangan dalam hal ini sebagai mitra, 5) Kepala Desa Randupadangan yang telah memberikan ijin kepada tim PHBD untuk melaksanakan kegiatan pemberdayaan di tersebut, 5) Terima kasih juga kami sampaikan kepada penyelengara atas kesempatannya untuk bergabung dalam Konferensi Nasional ke 6 PKM-CSR tahun 2020.

\section{REFERENSI}

Anwas, O.M. (2013). Pemberdayaan masyarakat di era global. Bandung: Penerbit Alfa Beta.

Astuti, Lifa Indri. (2015). Pemberdayaan Masyarakat dalam Pembangunan Pertanian Berkelanjutan (Studi Pada Desa Asmorobangun, Kecamatan Puncu, Kabupaten Kediri). Jurnal Administrasi Publik (JAP), Vol. 3, No. 11, Hal. 1886-1892.

Buhani, B. (2018). Pengolahan Sampah Rumah Tangga Berbasis Partisipasi Aktif dari Masyarakat Melalui Penerapan Metode 4Rp untuk Menghasilkan Kompos. Sakai Sambayan Jurnal Pengabdian Kepada Masyarakat, 2 (1), 7 13.

Ife, J. \& Tesoriero, F. (2008). Community development: alternatif pengembangan masyarakat di era globalisasi. Yogyakarta: Pustaka Pelajar.

Inayati, Nur. (2019). Pemberdayaan Masyarakat Melalui Program Kebun Sayur Asparagus (KSA) Dompet Dhuafa Di Desa Mlandi Kecamatan Gabung Kabupaten Wonosobo. Undergraduate (S1) thesis, UIN Walisongo

Mutaqin, T. H. (2010). Pengelolaan sampah limbah rumah tangga dengan komposer elektrik berbasis komunitas. Jurnal Litbang Sekda DiY Biro Adm. Pembang, 2 (2), 1-12.

Nalhadi, A., Syarifudin., Habibi, F., Fatah, A., Supriyadi,. (2020). Pemberdayaan Masyarakat Dalam Pemanfaatan Limbah Rumah Tangga Menjadi Pupuk Organik Cair. Wikrama Parahita: Jurnal Pengabdian Masyarakat 2020, Volume 4 Nomor 1: 43-46

Nasdian, F.T. (2014). Pengembangan masyarakat. Jakarta: Yayasan Pustaka Obor

Lingkungan Hidup Dan Kebencanaan 555 
Indonesia.

Suharto Edi. (2014). Kemiskinan dan Perlindungan Sosial di Indonesia Menggagas Model Jaminan Sosial Universal Bidang Kesehatan. Bandung : Alfabeta

Undang-Undang Republik Indonesia Nomor 19 Tahun 2013 Tentang Perlindungan dan Pemberdayaan Petani. Jakarta, Menteri Hukum dan Hak Asasi Manusia Republik Indonesia.

Wahyudi, Hardo and Jum'ati, Nurleila and Khanif, Fitroh Abdul and Andrianto, Ihwan and Pramitha, Miranda Dwi and Azizah, Nur Aini. (2018). Grey Water dan Air Banjir Layak Pakai sebagai Upaya Pemenuhan Kebutuhan Air Bersih. PKM-CSR, 1. pp. 375-385. ISSN 26553570 .

Wahyudi, Hardo and Jum'ati, Nurleila and Aini, Nurul. (2019). Teknologi Tepat Guna "Mekutus" Guna Mengurangi Resiko Pemasakan Telur Asin. PKM-CSR, 2. pp. 11891196. ISSN 2655-3570

Wesa, A., \& Suryono, Y. (2014). Kesejahteraan Ekonomi Masyarakat Peserta Pelatihan Kelompok Prakoperasi Di Kecamatan Namlea Kabupaten Buru. JPPM (Jurnal Pendidikan dan Pemberdayaan Masyarakat), Vol. 1, No. 2.

Widiyanto, A. F., Yuniarno, S., \& Kuswanto, K. (2015). Polusi Air Tanah Akibat Limbah Industri dan Limbah Rumah Tangga. KEMAS: Jurnal Kesehatan Masyarakat, 10 (2), 246254.

Wrihatnolo, Randy R dan Riant Nugroho Dwidjowijoto. (2007). Manajemen Pemberdayaan: Sebuah Pengantar dan Panduan untuk Pemberdayaan Masyarakat. Jakarta, Media Komputindo. 